\title{
Heavy Metals Existing in the Seaweed from the Romanian Coast of the Black Sea
}

Emin Cadar

Umf Carol Davila Bucharest, Faculty of Pharmacy, Bucharest, Romania

Ticuta Negreanu-Pîrjol

Ovidius University of Constanta, Faculty of Pharmacy, Constanta, Romania

Aneta Tomescu

Ovidius University of Constanta, Faculty of Medicine, Constanta, Romania

Stelian Paris

Ovidius University of Constanta, Faculty of Pharmacy, Constanta, Romania

Cristina-Luiza Erimia

Ovidius University of Constanta, Faculty of Pharmacy, Constanta, Romania

Bogdan Stefan Negreanu-Pîrjol

Ovidius University of Constanta, Faculty of Pharmacy, Constanta, Romania

\begin{abstract}
Seaweed is a natural treasure that can be intensely evaluated for therapeutic purposes. It is well known that the seaweed is an indicator of accumulation of heavy metals. In order to be used for medical purposes, kelp has to meet certain conditions concerning the content of heavy metals accumulated. In this work are presented the results of the analyzes concerning the content of heavy metals in two algae: Cystoseira barbata and Ceramium rubrum.
\end{abstract}

Keywords: marine algae, Black Sea, Cystoseira barbata, Ceramium rubrum

\section{Introduction}

Seaweed is a natural treasure that can be intensely evaluated for therapeutic purposes. During the past years, it became obvious that the ecosystem presents a marine algae excedent, which should be utilized in one way or another. Marine algae have been intensely studied [1] In the context of restructured economic activities and of increased exigencies with respect to the implementation of environment politics, a slight but continuous recovery process of the marine ecosystem has been taking place during last years. The superior exploitation of the marine biomass represents a highly important resource for the pharmaceutical industry, supplying raw material for the extraction of bioactive substances (vitamins, sterols, and aminoacids) and various other substances, the purity of which is strongly connected to the state of the marine ecosystem [2, 3]. Several studies regarding marine habitats where large amounts of seaweed can be found have been conducted $[4,5,6]$. Seaweed's rich content in bioactive compounds was outlined through a series of studies conducted by various researchers and published in diverse papers $[7,8,9]$. The antioxidant abilities of marine algae, as revealed by modern laboratory testing [10] and the attempts of obtaining seaweed gels [11], show the increased interest regarding the use of algae in medicine. It is well known that algae are an indicator of heavy metal accumulation. In order to be used for medical purposes, algae must comply with certain characteristics regarding content of heavy metals. This paper presents the results concerning the heavy metal content of 2 marine algae: Cystoseira barbata si Ceramium rubrum. 


\section{Research Methods}

Atomic absorption spectroscopy was used on seaweed samples, following these stages:

- Mineralization of the sample using the dry mineralization method;

- Establishment of calibration curves for the metals which will be determined;

- Exposure of mineralized solutions to flame ionization and measurement of specific absorbance, followed by calculation of heavy metal content; $\mathrm{Cd}(\lambda=228.8 \mathrm{~nm}), \mathrm{Cu}(\lambda=324.7 \mathrm{~nm}), \mathrm{Zn}(\lambda=213.9 \mathrm{~nm}), \mathrm{Cr}(\lambda=357.9 \mathrm{~nm})$, $\operatorname{Mn~}(\lambda=279.5 \mathrm{~nm}), \mathrm{Ni}(\lambda=232 \mathrm{~nm})$ şi $\mathrm{Pb}(\lambda=217 \mathrm{~nm})$.

\section{Drying and calcination in the programmed oven}

An established quantity of the sample is weighed (usually $10 \mathrm{to} 20 \mathrm{~g}$ ) in a crucible with an accuracy of $10 \mathrm{mg}$, according to the type of sample. The sample is treated with $3 \mathrm{~mL}$ of $\mathrm{Mg}\left(\mathrm{NO}_{3}\right)_{2}$, after which it is kept for two hours at a temperature of $100{ }^{\circ} \mathrm{C}$. The temperature is increased with a maximum speed of $50^{\circ} \mathrm{C} /$ hours to $350^{\circ} \mathrm{C}$, where it is kept for 3 hours for complete carbonization. The temperature is increased to $450^{\circ} \mathrm{C}$ and kept for 3 hours until a white ash is formed.

\section{Ash dissolution}

The crucible is removed from the oven and left to cool. The ash is moistened with $5 \mathrm{~mL} \mathrm{HCl}$ (1: 1), with an added $\mathrm{mL}$ of glacial acetic acid and a drop of perhydrol and is evaporated using a water bath or a hot sieve. After cooling, $5 \mathrm{~mL}$ of $\mathrm{HCL}$ and added acetic acid are added to the crucible, so that the ash comes into contact with the acid, after which it is heated for 5 minutes on a water bath. The residue is diluted in a volume of $5 \mathrm{~mL}$ of water and it is transferred in a $100 \mathrm{~mL}$ balloon. The mark is reached using warm water. After cooling, the mark is reached using cold water.

\section{Atomic absorption spectroscopy}

The analysis of mineral content was performed through flame atomic absorption spectroscopy (FAAS), an analysis method which is based on the property of an atom in fundamental electronic state to absorb radiant energy which is tallied to the wave length of one its resonance radiations. Microelements were determined from the algae. This method can be used for the following metals which can be found in algae samples: $\mathrm{Zn}, \mathrm{Cu}, \mathrm{Pb}$ and $\mathrm{Cd}$.

\section{Work equipment}

For this method, the following work equipment was used:

- $\quad$ Atomic absorption spectroscope GBC AVANTA (air/acetylene flame) and hollow-cathode lamps for all the analyzed elements;

- $\quad$ MLW112 calcination oven, thermo adjustable with a maximum temperature of $1100^{\circ} \mathrm{C}$;

- Mettler Tolede analytic scale with a measurement domain of $10 \mathrm{mg}-200 \mathrm{~g}$;

- $\quad$ Thermo adjustable electric water bath with a temperature domain of $100^{\circ} \mathrm{C}$;

- Thermo adjustable stove.

\section{Reactants and materials used:}

- $\quad$ Reactants for sample mineralization: hydrochloric acid, $d=1,18 \mathrm{~g} / \mathrm{mL}$, azotic acid, $\mathrm{d}=1,40 \mathrm{~g} / \mathrm{mL}$;

- Materials: porcelain crucibles, graded balloons, polyethylene vials, porcelain capsules, Berzelius glasses, quantitative filter paper with low porosity;

- Calibration stock solutions: solutions with a 1000 ppm concentration in the analysed element, from which different concentration solutions are obtained in order to draw calibration curves for each measured microelement.

\section{Calibration solutions}

- $\quad$ Lead calibration solution $1000 \mathrm{mg} / \mathrm{L}$. $1000 \mathrm{~g}$ of $\mathrm{Pb}$ are diluted in $7 \mathrm{~mL}$ azotic acid (4:3) in a $1 \mathrm{~L}$ graded balloon.

- Cadmium calibration solution $1000 \mathrm{mg} / \mathrm{L} .1000 \mathrm{~g}$ of $\mathrm{Cd}$ are diluted in $14 \mathrm{~mL}$ of water $+7 \mathrm{~mL}$ of azotic acid (4:3) in a $1 \mathrm{~L}$ graded balloon.

- Zinc calibration solution $1000 \mathrm{mg} / \mathrm{L}$. $1000 \mathrm{~g} \mathrm{Zn}$ are diluted in $14 \mathrm{~mL}$ water $+7 \mathrm{~mL}$ azotic acid (4:3) in a $1 \mathrm{~L}$ graded balloon. 
- Copper calibration solution $1000 \mathrm{mg} / \mathrm{L} .1000 \mathrm{~g} \mathrm{Cu}$ are diluted in $7 \mathrm{~mL}$ azotic acid (4:3) in a $1 \mathrm{~L}$ graded balloon.

\section{Results and Discussions}

Cystoseira barbata is part of the brown algae (Phaeophyta phylum), which represents a group of pluricellular macroscopic algae, the vast majority of them being found in seas and oceans. The low mineralization capacity of the tallus and the lack of fossils make appreciating their age and phylogenetic links quite hard. The vast majority of algae researchers believe that, due to the type of flagella and assimilating pigments, they are related with golden algae, which might actually represent their origin group. Brown algae have evolved, specialized and have adapted a lot, exclusively in the aquatic medium. They have not lead to the formation of other plant groups, as they are considered a closed phylogenetic group.

\section{Morphology and structure}

It is a large alga, characterized by polymorphism with a tallus that can reach $1.5-2 \mathrm{~m}$ in height. It latches to the substrate through a powerful disc-like spike, from which one or more cylindrical rods stem. On these rods, a high number of branches are formed, which gives the tallus a tree-like appearance.

Both primary and secondary branches can be cylindrical or flattened and can present with terminal receptacles. Receptacles are either cylindrical or cone-shaped and they contain conceptacles which produce reproductive elements. Alongside the branches, numerous air-containing vesicles arranged in a chain can be found.

\section{Growth cycle}

Even though the growth cycle of Cystoseira barbata is a monogenetic type, it does have certain particularities linked with the hydrobiologic conditions innate to the Black Sea. These are represented by two more active vegetation and fructification periods. The first and more intense one during spring (March-May) and the second one during autumn (SeptemberNovember). Another particularity is represented by the continuous formation of new branches and receptacles containing ovogones and antherida.

\section{Spread}

The species is spread in the Black Sea, where it forms a perennial association on a hard substrate, which is very valuable from an ecologic point of view. Currently, this association is very reduced, partly due to past freezing periods and partly due to pollution, increased water turbidity and substrate warping.

Ceramium rubrum is part of the red algae (Rhodophyta phylum), which encompasses uni- or pluricellular algae, which live in the aquatic medium, especially maritime environments, very few of them being found in sweet waters. Due to the membrane's mineralization ability, some species have fossilized and traces of red algae can be traced back to the Jurassic. The vast majority of algae researchers believe that they are related to blue algae, a theory sustained by the presence of phycoerythrin and phycocyanin pigments in both groups. They have evolved towards a superior vegetative apparatus and a specific reproductive mechanism, but they are still considered a closed phylogenetic group, as they have not lead to the formation of other plant groups.

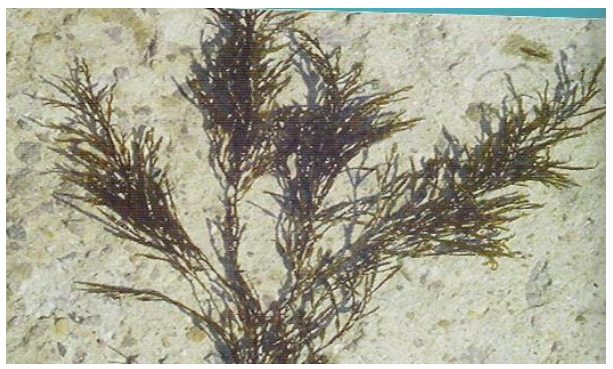

Fig. 1- Cystoseira barbata 


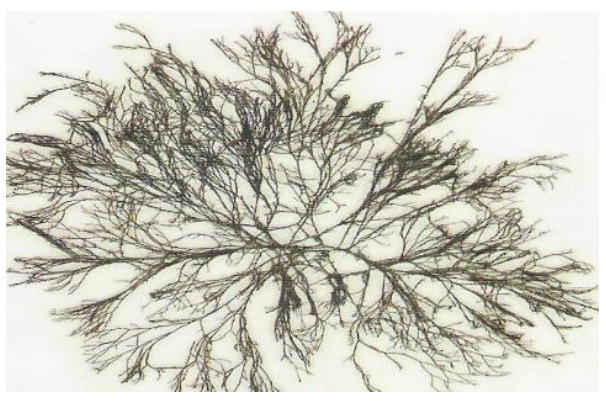

Fig. 2 - Ceramium rubrum

\section{Morphology and structure}

Ceramium rubrum presents as a dark red filamentous bush, fixed to the substrate through rhizoids. The filaments have a dihotomic ramification and growth begin with a single cell, which can be found at the apex and may sometimes be hidden. Each ramification ends with two short arms which form a tiny pliers. Filaments are made up of a single head to head row of cells, which makes it appear as an axial structure with the ends of the cells meeting at the knots. At each knot, a variable number of cells called periaxial cells is formed. These cells continue to divide leading to the formation of cortical cells. The species is characterized by a special type of polymorphism, which has lead to the identification of several varieties.

\section{Growth cycle}

Ceramium rubrum is characterized by a trigenetic growth cycle. The first generation is represented by the haploid gametophyte on which sexual organs can be found on the superior aspect. On the male gametophyte, spermatocytes are small and oval shaped. Through the emergenece of new haploids the cycle beings again and this succession of three generations can occur several times a year.

\section{Spread}

This alga is widely spread in the Atlantic Ocean, the Pacific, the Mediterranean Sea, and the Black Sea. It is an annual species, which sometimes widely colonizes the rocky substrates from the medio- and infraseaside and areas exposed to waves. On the Black Sea shore, it is found alongside the entire coastal area, on rocks, at depths of 0.5 to 4-5 m, all throughout the year, with a more accelerated growth during spring and summer.

Figures 1-4 present the calibration curves for the heavy metal content measured in the two types of algae.

- Sample 1 - Cystoseira Barbata (C.B); 11,9289 g were analyzed and mineralized according to the above mentioned methods.

- Sample 2 - Ceramium rubrum (C.R.); 14,2778 g were analyzed and mineralized according to the above mentioned methods.

Heavy metal content was determined using the following formula:

$[$ conc $]=\frac{C_{\text {curve }} x V_{\text {sample }}}{m_{\text {sample }}} ; \mathrm{mg} / \mathrm{kg}$ 


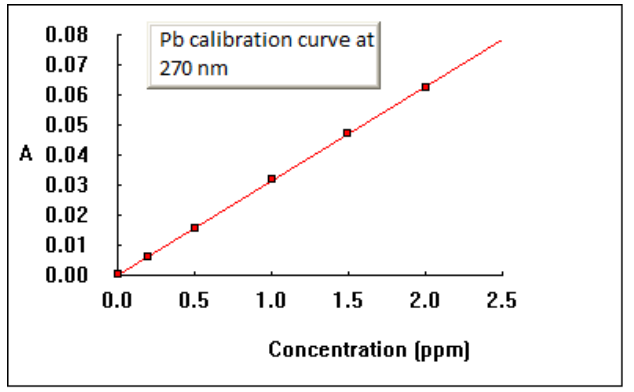

Fig. $1 \mathrm{~Pb}$ calibration curve $\quad(\lambda=270 \mathrm{~nm})$

Relationship: Linear Straight line calibration formula:

$A=0,03129 \times C+0,00048$

Correlation coefficient (r): 0,99988 (r)2:0,99975

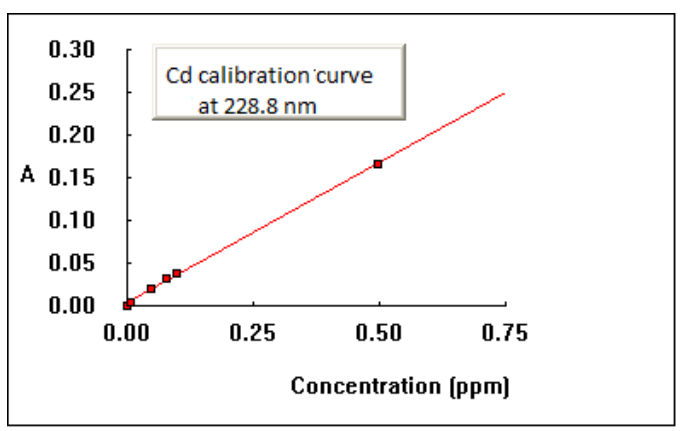

Fig. 2 Cd calibration curve $(\lambda=228,8 \mathrm{~nm})$

Relationship: Linear Straight line calibration formula:

$A=0,32804 \times C+0,00412$

Correlation coefficient (r): 0,99932 (r)2:0,99864

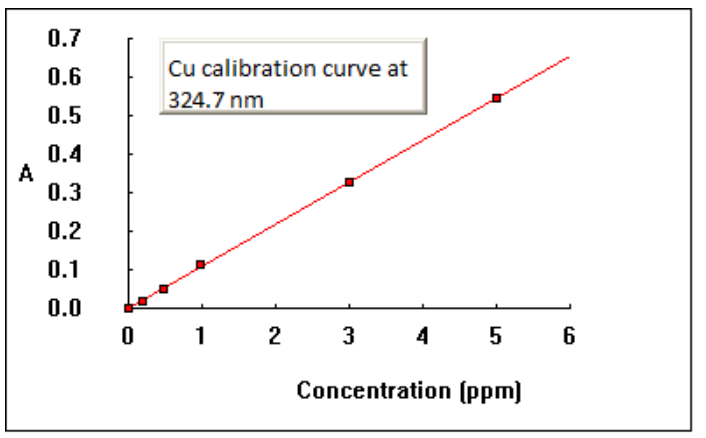

Fig. 3 Cu calibration curve $(\lambda=324,7 \mathrm{~nm})$ Relationship:

Linear Straight line calibration formula: $A=0,10941 \times C+0,00083$

Correlation coefficient $(r): 0,99984(r)^{2}: 0,99968$ 


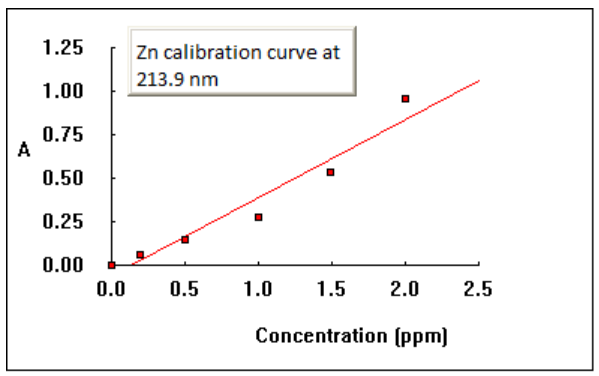

Fig. $4 \mathrm{Zn}$ calibration curve $(\lambda=231,9 \mathrm{~nm})$

Relationship: Linear Straight line calibration formula: A=0,45089 $\times$ C-0,05999

Correlation coefficient (r): 0,97070 (r) ${ }^{2}: 0,94226$

The results obtained for heavy metal content are presented in table 1.

Table 1. Heavy metal content of algae

\begin{tabular}{|l|l|l|l|l|}
\hline Type of alga & $\mathrm{Pb}(\mathrm{mg} / \mathrm{kg})$ & $\mathrm{Cd}(\mathrm{mg} / \mathrm{kg})$ & $\mathrm{Cu}(\mathrm{mg} / \mathrm{kg})$ & $\mathrm{Zn}(\mathrm{mg} / \mathrm{kg})$ \\
\hline Cystoseira barbata & 2,51 & 0,201 & 4,19 & 1,93 \\
\hline Ceramium rubrum & 5,04 & 0,231 & 6,58 & 6,72 \\
\hline
\end{tabular}

It can be observed that the red alga - Ceramium rubrum - has higher content of heavy metals compared to the brown alga - Cystoseira barbata. This is especially due to the biogeographic localization of these algae in the sea. Cystoseira barbata can be found in the shoreline area, at shallow depths, where solar radiation can penetrate, meaning that a part of the metals will become part of the biogeochimic circuit and used for photosynthesis. On the other hand, Ceramium rubrum lives at higher depths, where solar radiation cannot reach and photosynthesis does not occur. In addition, due to specific Black Sea currents, sediments of heavy metals are deposited and formed. Compared to the studies performed by biology and chemistry researchers from the Ovidius University of Constanta, an increase in heavy metal concentration can be observed for each of the alga species [21].

Table 2. Results regarding heavy metal content of red and brown algae studied in the year 2013 (ppm) in the Ovidius University of Constanta laboratories

\begin{tabular}{|l|l|l|}
\hline Species/location & $\mathrm{Cd}$ & $\mathrm{Pb}$ \\
\hline Ceramium rubrum & & \\
\hline Constanta - Modern & 5,76 & 3,77 \\
\hline Constanţa - Cazino & 8,03 & - \\
\hline Constanta - 3 Papuci & 11,21 & - \\
\hline Cystoseira barbata & & \\
\hline Constanta - Pescărie & 0,44 & - \\
\hline Constanta - 3 Papuci & 2,84 & - \\
\hline Constanta - Modern & 4,11 & - \\
\hline
\end{tabular}

Table 3. Results regarding heavy metal content of red and brown algae studied in the year 2014 (ppm) in the Ovidius University of Constanta laboratories

\begin{tabular}{|l|l|l|l|}
\hline Species/location & Cd & Mn & Zn \\
\hline Ceramium rubrum & 0,003 & 0,145 & 0,075 \\
\hline Constanta - Pescărie & 0,002 & 2,403 & 0,420 \\
\hline Constanta - Cazino &
\end{tabular}


There is a series of factors that influence the chemical composition of algae and that is: alga species, anatomical and morphological characteristics of the alga, harvesting area, harvesting season, and storage conditions. In what regards alga species, research has demonstrate that both the amount of alginic acid contained by the alga, as well as metal content vary according to species and even type, as is the case of red and brown algae.

Table $4 \mathrm{Cr}$, $\mathrm{Cu}$, and Fe concentration as determined by molecular absorption spectroscopy on algae from the Black Sea shore in the years 2013, 2014, and 2015

\begin{tabular}{|l|l|l|l|l|}
\hline Harvested algae & Harvest year & $\begin{array}{l}\text { Cr concentration } \\
\mathrm{mg} / \mathrm{Kg}\end{array}$ & $\begin{array}{l}\text { Cu concentration } \\
\mathrm{mg} / \mathrm{Kg}\end{array}$ & $\begin{array}{l}\text { Fe concentration } \\
\mathrm{mg} / \mathrm{Kg}\end{array}$ \\
\hline Cystoseira barbata & 2013 & 14.8 & 6.45 & 429.0 \\
Ceramium rubrum & & 3.92 & 22.43 & 363.8 \\
\hline Cystoseira barbata & 2014 & 14.47 & 8.30 & 254.70 \\
Ceramium rubrum & & 2.86 & 7.28 & 497.2 \\
\hline Cystoseira barbata & 2015 & - & 4,19 & - \\
Ceramium rubrum & & 28.47 & 6,58 & 263.4 \\
\hline
\end{tabular}

Compared to previous studies, we can observe that, throughout the years of analysis, the chrome concentration in brown algae has decreased, while for red algae it has increased to a worrisome level. Copper concentration in both species has decreased, while iron concentration is very important for the growth cycle and the development of the phytoplankton.

Copper concentration in Cystoseira barbata has decreased during one year, from 8,30 $\mu \mathrm{g} / \mathrm{g}$ in 2014 to 4,19 $\mu \mathrm{g} / \mathrm{g} 2015$. Copper concentration in Ceramium rubrum has decreased from 7,28 $\mu \mathrm{g} / \mathrm{g}$ in 2014 to $6,58 \mu \mathrm{g} / \mathrm{g}$ in 2015. The results obtained in 2015 for the two algae species is between STAS approved limits $(3,87-41,37 \mu \mathrm{g} / \mathrm{g})$.

\section{Conclusion}

It has been observed that concentration limits for heavy metals in the algae analysed in this study are comparable with results obtained in previous studies and are in accordance with the limits imposed by current legislation. The use of algae in the medical and pharmaceutical field can be optimized through the monitoring of heavy metal content in both the algae and their environment.

\section{References}

[1] P. Gayral, Les Algues, Morpfologie, Cytologie, Reproduction, Ecologie, 1975

[2] Rodica Sîrbu, Zaharia T., Negreanu-Pîrjol B.S, Nicolaev S., Bologa A.,Psegalinschi I, The Black Sea ecosystem - important potential source for pharmaceutical industry, Journal of Environmental Protection and Ecology, 11 (4): 1336-1348, 2010,

[3] Rodica Sîrbu, Negreanu-Pîrjol T., Paris S., Negreanu-Pîrjol B.Ş., Jurja S., A. Tomescu, „Important bioactive compounds from marine algae - potential source of pharmaceutical industry, Proceedings of $14^{\text {th }}$ International Multidisciplinary Scientific GeoConferences „Surveying Geology \& mining Ecology Management - SGEM 2014”, 17 - 26 June 2014, Albena, Bulgaria, Volume I, Section: Advances in Biotechnology, 381 - 388, 2014

[4] Rodica Sîrbu, T. Zaharia, A. Bechir, G. Lilios, S. Nicolaev, Characterisation of Marine Habitats Ecosystem and the Macro-algae Biodiversity along the Romanian Black Sea Shore Journal of Environmental Protection and Ecology, 13, No 1, 190-197, 2012,

[5] Rodica Sîrbu, T. Zaharia , A. M. Bechir, G. Lilios, S. Nicolaev , F. N. Roncea, Important Characteristics of the Marine Environment of the Romanian Littoral Coast -Favourable for Pharmaceutical Utilisat ions, Journal of Environmental Protection and Ecology 13, No 3A, 1842-1855, 2012,

[6] Rodica Sîrbu, T. Zaharia, A. Bechir, G. Lilios, S. Nicolaev, Characterisation Of Marine Habitats Ecosystem And The Macro-Algae Biodiversity Along The Romanian Black Sea Shore, The Journal of Environmental Protection and Ecology ,Vol. 13, No 1, 190-197, 2012

[7] Rodica Sîrbu, Aneta Tomescu, Sanda Jurja, Cristina-Luiza Erimia, Emin Cadar, Study of bioactiv pharmaceutical components from seaweeds from the Black Sea, Proceeding of $15^{\text {th }}$ International Multidisciplinary Scientific GeoConference SGEM 2015, 16-25 June, Bulgaria, 567-574, 2015

[8] Emin Cadar, Cristina-Luiza Erimia, Aneta Tomescu, Stelian Paris, Rodica Sîrbu, Marine Algae from Black Sea - Important Resources in the Pharmaceutical and Medical Research, European Journal of Interdisciplinary Studies, Vol.4 Nr. 1, 24-30, 2016 
[9] Constanţa Sava, Rodica SîRBU, Albertine LEON, "Hyphenated Techniques Applied for Active Principles Determination in Ceramium rubrum Algae from the Black Sea" Journal of Environmental Protection and Ecology Vol 13, No. 1, 2012, pag. 289-299, 2009,

[10] Ticuţa Negreanu-Pîrjol, B. Negreanu-Pîrjol, Rodica Sîrbu, G. Paraschiv, A. Meghea, "Comparative studies regarding the antioxidative activity of some therapeutic marine algae species along Romanian Black Sea Coast", Journal of Environmental Protection and Ecology vol.13, No. 3A, 1744 -1750. 2012,

[11] Rodica Sîrbu, T. Zaharia, V. Maximov, A.M. Bechir, M. Mariş, B. Negreanu-Pîrjol, D.Mariş, T. Negreanu-Pîrjol, M. Leca, E. M. Cadar, R. M. Stoicescu, L. Mocanu, S. Jurja, Clean bio-technologies for obtaining new pharmaceutical formulations based on collagen gels and marine algae extracts for medical applications, Journal of Environmental Protection and Ecology, 11(2), 654-665, 2010. 